\title{
Glucose variability for cardiovascular risk factors in type 2 diabetes: a meta-analysis
}

\author{
Shuang Liang, Hang Yin, Chunxiang Wei, Linjun Xie, Hua He* and Xiaoquan Liu* (1)
}

\begin{abstract}
Aims: It is consensus that glucose variability (GV) plays an important role in maccomplications of type 2 diabetes, but whether GV has a causal role is not yet clear for cardiovascular disease (CVD). This study sought to explore the effect on GV for CVD risk factors with type 2 diabetes.

Methods: The systematic literature search was performed to identify all GV and CVD risk factors, including total cholesterol (TC), LDL cholesterol (LDL-C), triglyceride (TG), HDL cholesterol (HDL-C), Body Mass Index (BMI), waist circumference (WC), High-Sensitivity C-reactive protein (Hs-CRP), Homeostasis model assessment (HOMA) and carotid intima-media thickness (IMT). Preferred Reporting Items was synthesized for Systematic reviews and Meta Analyses guideline. And the pooled analyses were undertaken using Review Manager 5.3.
\end{abstract}

Results: Twenty two studies were included with a total of 1143 patients in high glucose variability group (HGVG) and 1275 patients low glucose variability group (LGVG). Among these selected CVD risk factors, HOMA-IR and reduced IMT were affected by GV. HOMA-IR level was significantly lower in LGVG than in HGVG (MD $=0.58,95 \%$ Cl: 0.26 to 0.91, $P=0.0004)$, with evidence of heterogeneity between studies $\left(I^{2}=0 \% ; P=0.47\right)$.

Reduced IMT level was significantly lower in LGVG than in HGVG (SMD $=0.28,95 \% \mathrm{Cl}: 0.09$ to $0.47, P=0.003)$, with evidence of heterogeneity between studies $\left(I^{2}=0 \% ; P=0.48\right)$. However, the others were no significant statistical difference.

Conclusions: Among these selected CVD risk factors in type 2 diabetes, minimizing GV could improve insulin resistance and reduced IMT, consistent with a lowering in risk of CVD.

\section{Introduction}

Cardiovascular diseases (CVD) are the major causes of morbidity and mortality in type 2 diabetes [1], which death rate accounts for $75 \%$ [2]. It is widely accepted that lipid metabolism, Body Mass Index (BMI), waist circumference (WC), Homeostasis model assessment (HOMA), High-Sensitivity C-reactive protein (Hs-CRP) and carotid intima-media thickness (IMT) are dominant risk factors of cardiovascular disease (CVD) [3-5]. If not adequately controlled, these risk factors would increase CVD events, and they are also significant for clinical.

In prospective epidemiologic studies, the incidence of microvascular complications is directly linked with the degree of hyperglycemia, represented by the glycosylated hemoglobin level(HbA1c), which is expressed as mean blood glucose level during the previous 2 to 3 months [6].

\footnotetext{
* Correspondence: huahe827@163.com; Ixq@cpu.edu.cn

Department of Center of Drug Metabolism and Pharmacokinetics, China Pharmaceutical University, Nanjing, China
}

Meanwhile, UKPDS shows that an increase of $1 \%$ in HbA1c is associated with an increase of $37 \%$ in the risk of retinopathy or kidney disease [7]. However, ACCORD and ADVANCE have failed to provide an additional benefit in CVD with long-standing diabetes [8-10], even after maintaining near-normal $\mathrm{HbA1c}$ level in persons with type 2 diabetes. As a corollary, the uncertainty around HbA1c results related to clinical outcomes was augmented. Meanwhile, these findings suggest that near-normal HbA1c does not possibly improve CVD outcomes, so it's incompleteness need to fill out. Glucose variability(GV) mainly refer to as time in range and is unacceptable in hypo- and hyperglycemic range $(<70$ and $180 \mathrm{mg} / \mathrm{dL}$, respectively) [11], it has emerged as a key unmet need.

Although GV is emerging as an important dynamic parameter of diabetes control, its clinical importance is not fully characterized. Growing studies have reignited the emphasis that GV is a risk factor for diabetic complication. In general, much studies of GV in vitro laboratory 
evidence show that GV could increase production of reactive oxygen species and has a detrimental effect on endothelial dysfunction, even CVD [12]. While similar findings have also been shown in clinical studies [13], others have been unable to confirm any association [14]. Understanding mechanism of GV to CVD may help unravel some of the mystery about mac-complication in type 2 diabetes. So we aimed to describe association between CVD risk factor levels and GV in type 2 diabetes, providing opportunities for early diagnosis and targets for novel treatments.

\section{Methods}

\section{Literature search}

This review was performed by the Preferred Reporting Items for Systematic reviews and Meta Analyses guideline [15]. We searched PubMed, EMBASE, Cochrane Library, Web of science, Wan Fang Data and CNKI from 1970 to October 12, 2016 by using text words (diabetes [Title/Abstract]) AND (randomized clinical trial) AND (glucose variability OR glycemic variability OR glucose fluctuation OR glucose instability OR glycemic fluctuation). All relevant abstracts were obtained from our search. References from these studies were reviewed for additional citations and all potential articles.

\section{Trial eligibility and selection}

We included Chinese and English-language, full paper, randomized controlled clinical trials (RCTs) conducted in adult over 18 years of age patients with type 2 diabetes. The search strategy mainly focus on the association between GV and major CVD risk factors with type 2 diabetes, which include BMI [4], WC, TC, TG, HDL, LDL [3], Hs-CRP [5], HOMA and IMT. Studies that captured at least two group of glucose variability, including Mean blood glucose (MBG), coefficient of variation (CV), standard deviation(SD), mean amplitude of glycemic excursions (MAGE), mean of daily differences (MODD), continuous overall net glycemic action(CONGA), standard deviationglycosylated hemoglobin (SD-HbA1c), and standard deviation-Fasting plasma glucose (SD-FPG) [12, 16], assessed using either self-monitoring of blood glucose (SMBG) or continuous glucose monitoring (CGM) or reported a measure of GV were included in the review, and that were excluded if they had an impaired peripheral arterial disease, renal, liver, coronary heart disease, and stroke on the baseline. By contacting the corresponding authors, attempt to acquire studies that did not report the required data on GV and CVD risk factors.

Quality and characteristics of included studies were assessed regarding the methodological characteristics, statistical analysis, characteristics of the outcome by two reviewers. Where there was disagreement over the eligibility of a study, the article was discussion together and a consensus was reached.

\section{Data analysis and synthesis}

Because there are no generally accepted gold standard for assessing GV and little consensus for most accurate assessment of GV [16], and each has its own advantages and disadvantages, and it is no consistent assessment index of GV in all studies, therefore GV level are divided into two groups to ensure comprehensive. Comparable studies in terms of GV levels were pooled for metaanalysis if they were statistically significant between experimental group and control group, we define that low amplitude of GV was low glucose variability group (LGVG) and high amplitude of GV is high glucose variability group (HGVG).

In this meta-analysis, mean difference (MD) and standardized mean difference (SMD) were applied all the meta-analysis. Random effects models were used to consider study variation. $\mathrm{I}^{2}$ index is to estimate heterogeneity, namely used to determine whether differences exist between studies [17]. Heterogeneity is low if I $<30 \%$, heterogeneity is moderate if $\mathrm{I}^{2}$ is $30 \%-50 \%$, and heterogeneity is concluded if $P<0.10$ and $\mathrm{I}^{2}>50 \%$ [17]. Analyses were undertaken using Review Manager 5.3.

\section{Bias assessment}

Bias, being caused by literature search and data analysis, can lead to under- or over-estimation of the true intervention effects in clinical trials. In this meta-analysis, publication bias was assessed using Egger's test [18]. Sensitivity analyses were assessed by removing one study at a time on the pooled estimate.

Note: Body Mass Index (BMI), waist circumference (WC), Total Cholesterol (TC), triglyceride (TG), highdensity lipoprotein (HDL), low-density lipoprotein (LDL), C-reactive protein (CRP), Homeostasis model assessment (HOMA) and Length of Inner Metatarsal Tubercle (IMT).

\section{Results}

Among these studies, four authors were contacted for missing data, but no authors provided additional information, so 22 studies are included for full-text review in the meta-analysis, representing a total sample of 1143 patients in HGVG and 1275 patients in LGVG, 1183 studies are removed based on our inclusion and exclusion criteria (Fig. 1), and the vast majority studies were excluded as reviews or not reporting either a measure of GV or no the associated CVD risk factors of interest. These eligible studies contained data on two different groups. And the studies characteristics are summarized in Table 1. Sensitivity analyses revealed that no particular study affected significantly the summary effects for 


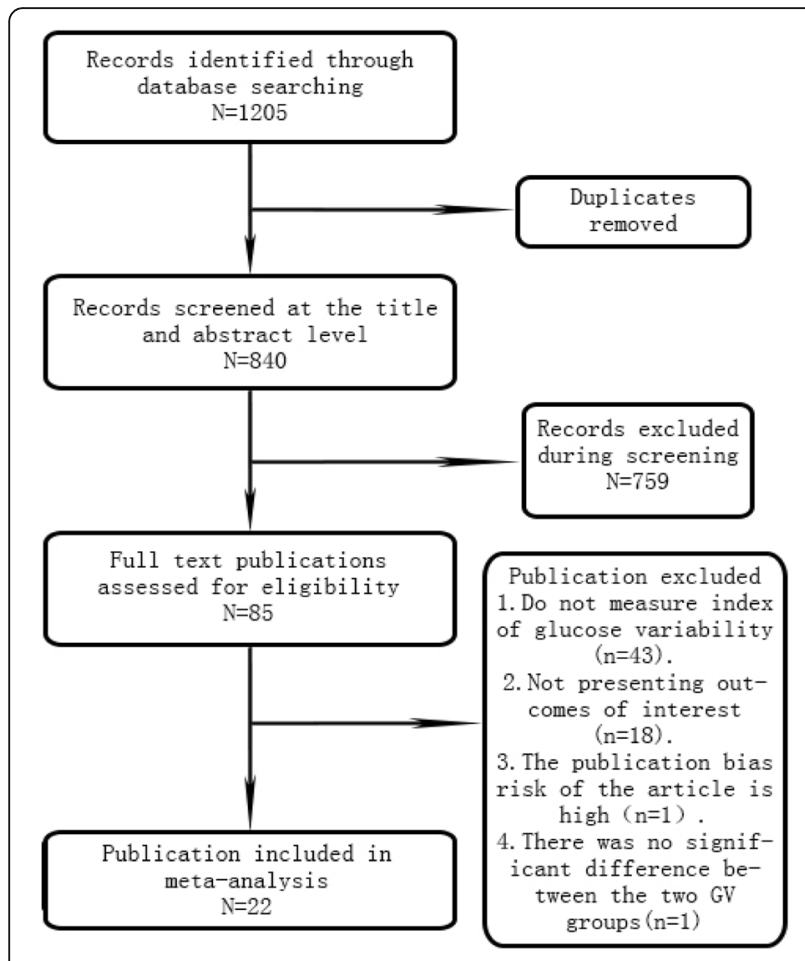

Fig. 1 Flow diagram for identifying eligible studies

CVD risk factors. Findings from Egger's test supported the finding that except LDL, others were no publication bias (Table 2). When one article was excluded, the publication bias of LDL is non-existent (P: 0.328).

The characteristics of the studied populations varied with baseline values ranging from $42 \%$ to $70 \%$ for the proportion of males, 18 to 80 years for age. The length of follow-up ranged from $1 / 2$ to 52 months.

\section{Effect on body mass index and waist circumference}

Nine studies are received in BMI, comprising 338 patients of low GV and 353 patients of high GV, and baseline mean values range from $23\left(\mathrm{~kg} / \mathrm{m}^{2}\right)$ to $26\left(\mathrm{~kg} / \mathrm{m}^{2}\right)$. Reduction in BMI was observed in 4 of the 10 studies. The meta-analysis revealed that BMI levels were not significantly higher in HGVG than in LGVG (mean difference $[\mathrm{MD}]=0.28 \mathrm{~kg} / \mathrm{m}^{2}$ (95\% confidence interval $[95 \%$ $\mathrm{CI}]-0.1$ to 0.67 ) with evidence of heterogeneity between studies $\left(\mathrm{I}^{2}=32 \% ; P=0.16\right)$, and reduced BMI levels also did not reach statistical significance $\left(M D=0.01 \mathrm{~kg} / \mathrm{m}^{2}\right.$, 95\% CI: $=-0.07$ to $0.09 ; \mathrm{I}^{2}=23 \% ; P=0.28$ ) (Table 3 , Additional file 1: Figure S1).

Five studies comprise 165 patients of high GV and 159 patients of low GV in WC. The meta-analysis revealed that waist circumference level was not associated with glucose variability level $(\mathrm{MD}=1.11 \mathrm{~cm}, 95 \% \mathrm{CI}:=-0.99$ to 3.22), with evidence of heterogeneity between studies $\left(\mathrm{I}^{2}=0 \% ; P=0.49\right)$ and reduced WC levels also did not reach statistical significance $(\mathrm{MD}=1.35,95 \% \mathrm{CI}$ : $=-1.13$ to $3.83 ; \mathrm{I}^{2}=0 \% ; P=0.81$ ) (Table 3, Additional file 1: Figure S2).

\section{Effect on insulin secretion and insulin resistant}

Eight studies of HOMA-IR comprise 406 patients of high GV and 399 patients of low GV. Reduction in HOMA-IR was observed in $2[19,20]$ of the 8 studies. The meta-analysis revealed that HOMA-IR level was significantly lower in LGVG than in HGVG (MD $=0.58$, $95 \% \mathrm{CI}:=0.26$ to $0.91, P=0.0004)$, with evidence of heterogeneity between studies $\left(\mathrm{I}^{2}=0 \% ; P=0.47\right)$, however, reduced HOMA-IR were not statistical significance $\left(\mathrm{MD}=0.18,95 \% \mathrm{CI}:=-0.00\right.$ to $\left.0.37 ; \mathrm{I}^{2}=0 \% ; P=0.43\right)$ (Table 3, Fig 2).

Six studies of HOMA- $\beta$ comprise 302 patients of high GV and 299 patients of low GV. One of five studies in $\beta$ cell function was an increase after lower GV. The pooled weighted mean difference was $1.53(95 \% \mathrm{CI}=-2.94$ to 6.00, $P=0.5$ ), with evidence of heterogeneity between studies $\left(\mathrm{I}^{2}=0 \% ; P=0.95\right)$. And HOMA- $\beta$ of the pooled mean change was $8.44(95 \% \mathrm{CI}=-4.53$ to $21.4, P=0.2)$, with evidence of heterogeneity between studies $\left(\mathrm{I}^{2}=0 \%\right.$; $P=0.5$ ) (Table 3, Additional file 1: Figure S7). Whatever final levels and changes of HOMA- $\beta$ both were no association with GV.

\section{Effect on lipid metabolism}

The meta-analysis revealed that lipid metabolism level was not associated with glucose variability based on TC, TG, HDL and LDL levels. Eighteen studies about TC, it is that $\mathrm{MD}=-0.03 \mathrm{mmol} / \mathrm{l}, 95 \% \mathrm{CI}:=-0.06$ to 0.00 , with evidence of heterogeneity between studies $\left(\mathrm{I}^{2}=0 \% ; P=0.78\right)$ (Table 3). Twenty-two studies about TG, it is that $\mathrm{MD}=0.02 \mathrm{mmol} / \mathrm{l}, 95 \% \mathrm{CI}:=-0.07$ to 0.11 , with evidence of heterogeneity between studies $\left(\mathrm{I}^{2}=28 \% ; P=0.15\right)$ (Table 3 , Fig 2). Eighteen studies about HDL, it is that $\mathrm{MD}=-0.01 \mathrm{mmol} / \mathrm{l}, 95 \% \mathrm{CI}:=-0.05$ to 0.03 , with evidence of heterogeneity between studies $\left(\mathrm{I}^{2}=24 \% ; P=0.24\right)$ (Table 3, Additional file 1: Figure S3). Twenty studies about $\mathrm{LDL}$, it is that $\mathrm{MD}=-0.05 \mathrm{mmol} / \mathrm{l}, 95 \% \mathrm{CI}:=-0.13$ to 0.02 , with evidence of heterogeneity between studies $\left(\mathrm{I}^{2}=0 \% ; P=0.57\right)$ (Table 3, Additional file 1: Figure S4).

However, we found that GV were associated with reduced TG $(\mathrm{MD}=0.19 \mathrm{mmol} / \mathrm{l} ; 95 \% \mathrm{CI}$ : [0.07, 0.3]; $\left.I^{2}=36 \% ; P=0.17\right)$, and a trend towards reduced others' levels which did not reach statistical significance: TC $(\mathrm{MD}=-0.12 \mathrm{mmol} / \mathrm{l} ; 95 \% \mathrm{CI}:[-0.26$, $\left.0.01] ; \mathrm{I}^{2}=33 \% ; P=0.18\right), \mathrm{HDL}(\mathrm{MD}=0.02 \mathrm{mmol} / \mathrm{l}$; 95\% CI: $\left.[-0.02,0.05] ; \mathrm{I}^{2}=31 \% ; P=0.12\right)$ and LDL $\left(\mathrm{MD}=-0.01 \mathrm{mmol} / \mathrm{l} ; 95 \% \mathrm{CI}:[-0.10,0.07] ; \mathrm{I}^{2}=21 \%\right.$; $P=0.21)$ (Table 3$)$. 
Table 1 Characteristics of included studies

\begin{tabular}{|c|c|c|c|c|c|c|c|}
\hline Study,Year & $\begin{array}{l}\text { Sample Size (n) } \\
\text { (high GV /low GV) }\end{array}$ & $\begin{array}{l}\text { Glucose variability } \\
\text { indice }\end{array}$ & $\begin{array}{l}\text { Follow up } \\
\text { (month) }\end{array}$ & $\begin{array}{l}\text { Age } \\
\text { (mean/arrange) }\end{array}$ & $\begin{array}{l}\text { Men } \\
(\%)\end{array}$ & Ethnics & CVD risk factors \\
\hline $\begin{array}{l}\text { Panwei Mu } \\
2011[31]\end{array}$ & $126 / 124$ & CV-FBG & 3 & 40 & 42.8 & Xanthous & $\begin{array}{l}\text { TC,TG,HDL,LDL,HOMA- } \\
\text { IR,HOMA- } \beta\end{array}$ \\
\hline $\begin{array}{l}\text { H.J. Yoo } \\
2008[32]\end{array}$ & $28 / 29$ & MAGE & 3 & $20-80$ & 42.1 & Xanthous & TC,TG,HDL,LDL,BMI,WC \\
\hline $\begin{array}{l}\text { Su Guirong } \\
2014[33]\end{array}$ & $28 / 27$ & MBG SDBG MODD MAGE & 12 & 50 & 52 & Xanthous & TC,TG,HDL,LDL,BMI,HOMA-IR \\
\hline $\begin{array}{l}\text { Shi Dou Lin } \\
2011[34]\end{array}$ & $20 / 20$ & MBG SD MODD CONGA & 6 & $30-70$ & 57.5 & Xanthous & BMI,TC,TG,HDL,LDL \\
\hline $\begin{array}{l}\text { Guoyue Yuan } \\
2015 \text { [35] }\end{array}$ & $104 / 108$ & CV MAGE & 0.5 & 49 & 67.00 & Xanthous & $\begin{array}{l}\text { BMI,TC,TG,HDL,LDL,Hs- } \\
\text { CRP,HOMA-IR }\end{array}$ \\
\hline $\begin{array}{l}\text { Weiping Sun } \\
2016[36]\end{array}$ & $52 / 51$ & SD-HbA1c MAGE & 6 & $30-70$ & 52.78 & Xanthous & $\begin{array}{l}\text { TC,TG,LDL,HDL,HOMA- } \\
\text { IR,HOMA- } \beta\end{array}$ \\
\hline $\begin{array}{l}\text { HunSung Kim } \\
2013 \text { [37] }\end{array}$ & $17 / 16$ & MBG SD MAGE & 2 & $18-80$ & 57.58 & Xanthous & $\mathrm{TC}, \mathrm{TG}, \mathrm{HDL}, \mathrm{LDL}$ \\
\hline $\begin{array}{l}\text { Claudia De Natale } \\
2009 \text { [38] }\end{array}$ & $13 / 5$ & CV MAGE & 1 & 59 & 66.67 & Caucasian & TC,TG,LDL,HDL \\
\hline $\begin{array}{l}\text { Jae-Hyoung Cho } \\
2006 \text { [39] }\end{array}$ & $40 / 40$ & SD-HbA1c & 30 & $\geq 30$ & 61.25 & Xanthous & $\mathrm{TC}, \mathrm{TG}, \mathrm{HDL}$ \\
\hline $\begin{array}{l}\text { Yu Qian Bao } \\
2010 \text { [19] }\end{array}$ & $20 / 20$ & MBG MODD MAGE & 2 & $34-70$ & 41.3 & Xanthous & $\begin{array}{l}\text { TC,TG,HDL,LDL,BMI,WC,HOMA- } \\
\text { IR,HOMA- } \beta\end{array}$ \\
\hline $\begin{array}{l}\text { Helene von Bibra } \\
2016 \text { [40] }\end{array}$ & $48 / 61$ & SD-HbA1c MAGE & 36 & $35-85$ & 70.6 & Caucasian & TC,TG,HDL,LDL,Hs-CRP,IMT \\
\hline $\begin{array}{l}\text { John B Buse } \\
2016 \text { [41] }\end{array}$ & $159 / 307$ & MAGE & 13 & 60.4 & 57.5 & Caucasian & TG,HDL,LDL \\
\hline $\begin{array}{l}\text { Tomoya Mita } \\
2016[42]\end{array}$ & $152 / 151$ & SD-HbA1c SD-FBG & 6 & $\geq 30$ & 58.36 & Xanthous & IMT,TC, LDL, HDL \\
\hline $\begin{array}{l}\text { Jeannie Tay } \\
2015[43]\end{array}$ & $47 / 46$ & $\begin{array}{l}\text { MBG SD MAGE MODD } \\
\text { CONGA-1 CONGA-4 }\end{array}$ & 6 & $35-68$ & 67.74 & Caucasian & $\begin{array}{l}\text { WC,HOMA-IR,HOMA- } \beta \text {, } \\
\text { Hs-CRP,TC,TG,HDL,LDL }\end{array}$ \\
\hline $\begin{array}{l}\text { Jeannie Tay } \\
2015 \text { [44] }\end{array}$ & $37 / 41$ & $\begin{array}{l}\text { MAGE SD CONGA-1 CONGA- } \\
4\end{array}$ & 13 & $35-68$ & 57.39 & Caucasian & $\begin{array}{l}\text { TC,TG,HDL,LDL,Hs-CRP,HOMA- } \\
\text { IR,HOMA- } \beta\end{array}$ \\
\hline $\begin{array}{l}\text { Heng Wan } \\
2016[45]\end{array}$ & $30 / 30$ & SD MBG MAGE & 8 & $30-70$ & 46.5 & Xanthous & $\mathrm{BMI}, \mathrm{TC}, \mathrm{TG}, \mathrm{HDL}, \mathrm{LDL}$ \\
\hline $\begin{array}{l}\text { Huang Zhanqiang } \\
2012[46]\end{array}$ & $40 / 40$ & CV-FPG SDBG & 3 & $\geq 60$ & 66.25 & Xanthous & TC,TG,HDL,LDL \\
\hline $\begin{array}{l}\text { Qiang Zhou } \\
2008[47]\end{array}$ & $56 / 50$ & MAGE & 6 & $20-75$ & 62 & Xanthous & BMI, WC \\
\hline $\begin{array}{l}\text { Yanzhen Ye } \\
2014 \text { [48] }\end{array}$ & $22 / 28$ & MAGE SD & 18 & 46 & 60.72 & Xanthous & TC,TG,HDL,LDL \\
\hline $\begin{array}{l}\text { Ruiting He } \\
2016 \text { [49] }\end{array}$ & $60 / 60$ & MBG MAGE SD LAGE & 10 & 56 & 50 & Xanthous & $\mathrm{BMI}, \mathrm{TC}, \mathrm{TG}, \mathrm{LDL}, \mathrm{HDL}$ \\
\hline $\begin{array}{l}\text { Shuijing Zhou } \\
2012 \text { [20] }\end{array}$ & $23 / 10$ & MAGE & 24 & $20-70$ & 50.94 & Xanthous & BMI,TG,TC,HDL,LDL,IMT \\
\hline $\begin{array}{l}\text { Wang Ruiping } \\
2015 \text { [50] }\end{array}$ & $29 / 27$ & MAGE & 1 & $60-80$ & 58.93 & Xanthous & TC,TG,WC \\
\hline
\end{tabular}

Note: Body Mass Index (BMI), waist circumference (WC), Total Cholesterol (TC), triglyceride (TG), high-density lipoprotein (HDL), low-density lipoprotein (LDL), C-reactive protein (CRP), Homeostasis model assessment (HOMA) and Length of Inner Metatarsal Tubercle (IMT)

Effect on inner metatarsal tubercle and high sensitivity $C$ reactive protein

Seven studies of Hs-CRP comprise 417 patients of high GV and 426 patients of low GV. The metaanalysis revealed that Hs-CRP level was not associated with glucose variability $(\mathrm{MD}=-0.24 \mathrm{ng} / \mathrm{ml}, 95 \%$
CI: $=-0.73$ to $0.25, P=0.33)$, with evidence of heterogeneity between studies $\left(\mathrm{I}^{2}=0 \% ; P=0.6\right)$ and reduced WC levels also did not reach statistical significance $(\mathrm{MD}=0.33 \mathrm{ng} / \mathrm{ml}, 95 \% \mathrm{CI}:=-0.09$ to $0.76 ; \mathrm{I}^{2}=12 \% ; P=0.33$ ) (Table 3 , Additional file 1 : Figure S6). 
Table 2 Summary of publication bias with Eggers test

\begin{tabular}{clll}
\hline Egger test & & $\mathrm{t}(95 \% \mathrm{Cl})$ & $P$ \\
\hline BMI & change & $-0.17[4.48,-4.85]$ & 0.88 \\
WC & final value & $0.1[2.61,-2.39]$ & 0.92 \\
TC & final value & $1.51[-2.98,8.36]$ & 0.23 \\
& change & $0.78[4.07,-2.17]$ & 0.47 \\
TG & final value & $-0.5[0.41,-0.66]$ & 0.63 \\
& change & $0.68[-0.36,0.59]$ & 0.73 \\
HDL & final value & $1.27[-0.47,1.85]$ & 0.22 \\
& change & $0.16[-3.43,3.90]$ & 0.88 \\
LDL & final value & $-0.28[-1.32,1.02]$ & 0.79 \\
& change & $0.14[-2.47,2.77]$ & 0.891 \\
HOMA-IR & final value & $-3.03[-2.81,-0.48]$ & 0.009 \\
& change & $2.85[-1.17,5.74]$ & 0.104 \\
HOMA- $\beta$ & final value & $1.08[-1.11,2.73]$ & 0.329 \\
& change & $-2.45[-6.50,4.40]$ & 0.247 \\
HS-CRP & final value & $3.87[-0.05,0.92]$ & 0.061 \\
& change & $-1.99[-3.72,1.37]$ & 0.185 \\
IMT & final value & $-0.76[-4.7,3.28]$ & 0.525 \\
\hline
\end{tabular}

Table 3 Summary of results for CVD risk factors

\begin{tabular}{|c|c|c|c|c|c|c|c|c|c|c|c|}
\hline \multicolumn{2}{|c|}{ CVD risk factors } & \multirow{3}{*}{$\begin{array}{l}\text { Population } \\
\text { overall }\end{array}$} & \multirow{3}{*}{$\begin{array}{l}\text { No.of } \\
\text { studies }\end{array}$} & \multicolumn{2}{|c|}{ No.of patients } & \multicolumn{3}{|c|}{ Test of association } & \multicolumn{3}{|c|}{ Test of heterogeneity } \\
\hline & & & & \multirow{2}{*}{$\begin{array}{l}\mathrm{H} \mathrm{GV} \\
218\end{array}$} & \multirow{2}{*}{$\frac{\mathrm{L} \mathrm{GV}}{225}$} & \multirow{2}{*}{$\begin{array}{l}\mathrm{MD} \\
0.01\end{array}$} & \multirow{2}{*}{$\frac{95 \% \mathrm{Cl}}{[-0.07,0.09]}$} & \multirow{2}{*}{$\frac{P \text {-value }}{0.82}$} & \multirow{2}{*}{$\begin{array}{l}\text { Model } \\
R\end{array}$} & \multirow{2}{*}{$\begin{array}{l}P \text {-value } \\
0.28\end{array}$} & \multirow{2}{*}{$\frac{1^{2}}{23 \%}$} \\
\hline BMI & change & & & & & & & & & & \\
\hline & final value & overall & 9 & 353 & 338 & 0.28 & {$[-0.10,0.67]$} & 0.15 & $\mathrm{R}$ & 0.16 & $32 \%$ \\
\hline \multirow[t]{2}{*}{ WC } & change & overall & 2 & 84 & 87 & 1.35 & {$[-1.13,3.83]$} & 0.29 & $\mathrm{R}$ & 0.81 & $0 \%$ \\
\hline & final value & overall & 5 & 165 & 159 & 1.11 & {$[-0.99,3.22]$} & 0.30 & $\mathrm{R}$ & 0.49 & $0 \%$ \\
\hline \multirow[t]{2}{*}{ TC } & change & overall & 7 & 468 & 488 & -0.12 & {$[-0.26,0.01]$} & 0.07 & $\mathrm{R}$ & 0.18 & $33 \%$ \\
\hline & final value & overall & 16 & 661 & 639 & -0.03 & {$[-0.06,0.00]$} & 0.06 & $\mathrm{R}$ & 0.78 & $0 \%$ \\
\hline \multirow[t]{2}{*}{ TG } & change & overall & 6 & 317 & 338 & 0.19 & {$[0.07,0.30]$} & 0.002 & $\mathrm{R}$ & 0.17 & $36 \%$ \\
\hline & final value & overall & 16 & 807 & 939 & 0.02 & {$[-0.07,0.11]$} & 0.67 & $\mathrm{R}$ & 0.15 & $28 \%$ \\
\hline \multirow[t]{2}{*}{$\mathrm{HDL}$} & change & overall & 16 & 759 & 891 & 0.02 & {$[-0.02,0.05]$} & 0.36 & $\mathrm{R}$ & 0.12 & $31 \%$ \\
\hline & final value & overall & 7 & 451 & 474 & -0.01 & {$[-0.05,0.03]$} & 0.70 & $\mathrm{R}$ & 0.24 & $24 \%$ \\
\hline \multirow[t]{2}{*}{ LDL } & change & overall & 16 & 779 & 911 & -0.01 & {$[-0.10,0.07]$} & 0.74 & $\mathrm{R}$ & 0.21 & $21 \%$ \\
\hline & final value & overall & 7 & 468 & 483 & -0.05 & {$[-0.13,0.02]$} & 0.13 & $\mathrm{R}$ & 0.57 & $0 \%$ \\
\hline \multirow[t]{2}{*}{ HOMA-IR } & change & overall & 4 & 247 & 256 & 0.18 & {$[-0.00,0.37]$} & 0.05 & $\mathrm{R}$ & 0.43 & $0 \%$ \\
\hline & final value & overall & 7 & 386 & 378 & 0.58 & {$[0.26,0.91]$} & 0.0004 & $\mathrm{R}$ & 0.47 & $0 \%$ \\
\hline \multirow[t]{2}{*}{ HOMA- $\beta$} & change & overall & 3 & 147 & 144 & 8.44 & {$[-4.53,21.4]$} & 0.2 & $\mathrm{R}$ & 0.5 & $0 \%$ \\
\hline & final value & overall & 4 & 239 & 236 & 1.53 & {$[-2.94,6.00]$} & 0.5 & $\mathrm{R}$ & 0.95 & $0 \%$ \\
\hline \multirow[t]{2}{*}{ HS-CRP } & change & overall & 4 & 255 & 271 & 0.33 & {$[-0.09,0.76]$} & 0.12 & $\mathrm{R}$ & 0.33 & $12 \%$ \\
\hline & final value & overall & 4 & 179 & 178 & -0.24 & {$[-0.73,0.25]$} & 0.33 & $\mathrm{R}$ & 0.60 & $0 \%$ \\
\hline IMT & change & overall & 3 & 224 & 226 & 0.28 (SMD) & {$[0.09,0.47]$} & 0.003 & R & 0.48 & $0 \%$ \\
\hline
\end{tabular}

Three studies of IMT comprise 224 patients of high GV and 226 patients of low GV. The meta-analysis revealed that reduced IMT level was significantly lower in LGVG than in HGVG (SMD $=0.28 \mathrm{~mm}, 95 \% \mathrm{CI}:=0.09$ to $0.47, P=0.003$ ), with evidence of heterogeneity between studies $\left(\mathrm{I}^{2}=0 \% ; P=0.48\right)$ (Table 3, Fig. 2).

\section{Discussion}

The meta-analysis focuses on how GV affect CVD risk factors among 2 diabetes patients, as L Nalysnyk reported that GV was a significant positive association with the development or progression of diabetic retinopathy, even cardiovascular events and mortality [21]. This meta-analysis showed that glucose variability might affect IMT and insulin resistant. However, the effects of GV on BMI, WC, HOMA- $\beta$, lipid metabolism and HsCRP were not statistically significant. At the same time, Brohall G reported that impaired glucose tolerance showed a higher IMT [22]. That explained that it might be association among GV, IMT and insulin resistant, in order to provide opportunities for novel treatments.

IMT has been shown a significant predictor of CVD patients [23]. In this meta-analysis, minimizing GV is accompanied by a reduction of IMT with an estimated magnitude between 0.09 and $0.47 \mathrm{~mm}$, which is consistent with an estimated $11 \%$ to $59 \%$ reduction in risk of myocardial infarction and a $13 \%$ to $70 \%$ reduction in risk 
(i)

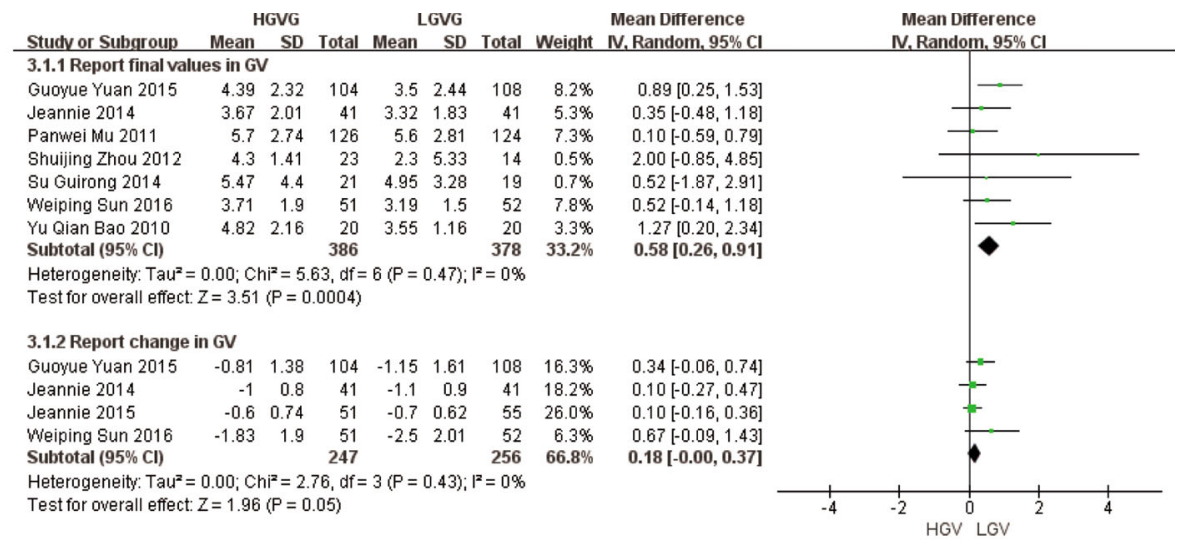

(ii)

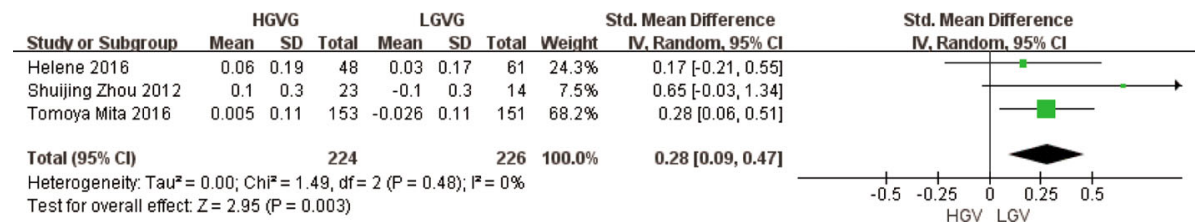

(iii)

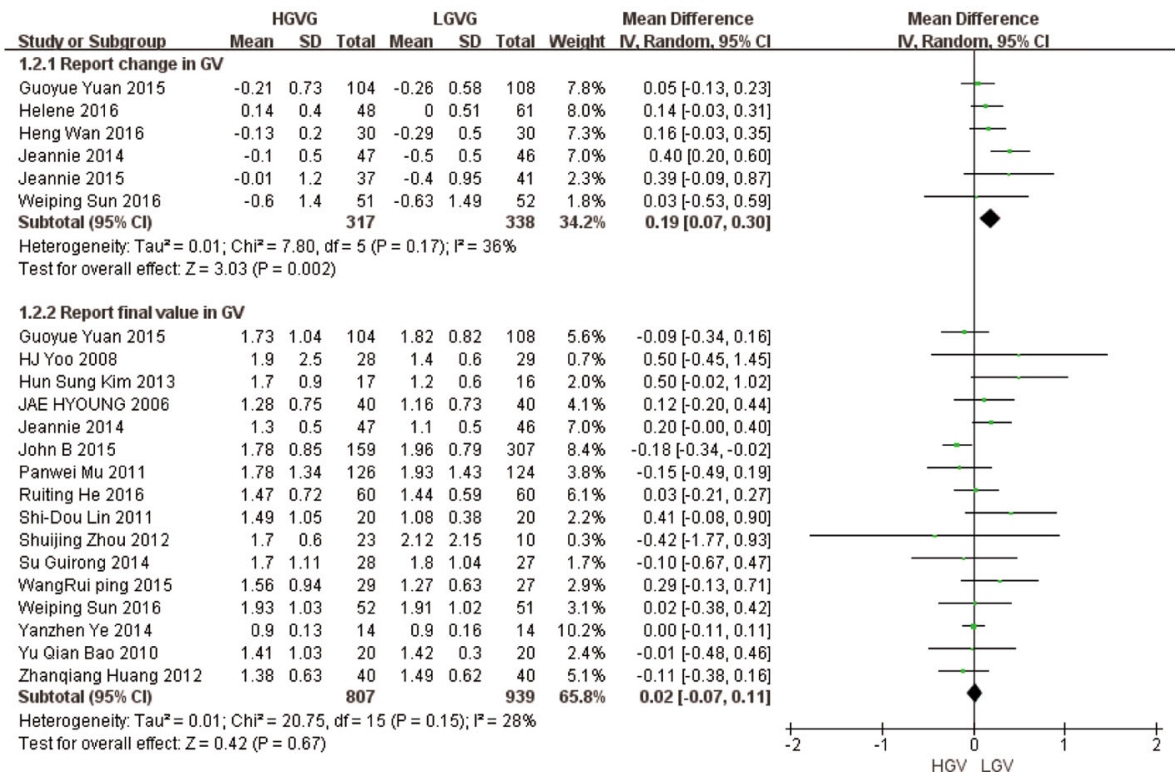

Fig. 2 Forest plots of the effect of glucose variability for CVD risk factors in type 2 diabetes patients, showing differences in outcomes of trials with LGVG and HGVG. (i) Effect of GV on HOMA-IR. (ii) Effect of GV on IMT. (iii) Effect of GV on TG. (CL: confidence interval. LGVG: low glucose variability group. HGVG: high glucose variability group. IMT: carotid intima-media thickness TG: triglyceride

of stroke [24]. Meanwhile, some studies found that IMT was associated with Phosphoinositide 3-kinase (PI3K) [25] and AMPK pathway [26], suggesting GV possibly affect IMT through PI3K or AMPK pathway.

Verona Diabetes Complicated Study [27] previously postulated that HOMA-IR was also an significant predictor of cardiovascular disease in type 2 diabetes.
ApoE2/2 mice without insulin resistance, which had a single allele of the insulin receptor deleted, will not enhance the severity of atherosclerosis [28]. It has long been known that the insulin resistance in type 2 diabetes is caused by decrease in receptor concentration and kinase activity, the concentration and phosphorylation of insulin receptor substrate-1/-2, PI3K activity, and 
glucose transporter translocation [29]. Thus insulin resistant plays a significant role on mac-complications, especially atherosclerosis. Now that GV could affect insulin resistant, so the improvement of GV might have beneficial effects not only on glucose control but also on CVD in type 2 diabetes.

Evidence continues to point to PI3K, which is only common between insulin resistant and IMT, and AKT is activated downstream of PI3K. It is also consistent that people with impaired glucose tolerance show a higher IMT [22]. As our knowledge, PI3K/Akt mediates recruitment of glucose transporter GLUT4 and also enhances glucose oxidation, and it can effect endothelial function and inhibit cell apoptosis of myocardial cells. So according to our meta-analysis, we speculated that the one pathogenesis of GV is probably to affect PI3K/AKT single pathway, then aggravated glucose tolerance and increased IMT levels, further leaded to CVD events.

Although no statistical significance between lipid metabolism and GV in this meta-analysis, change of TG was effected by GV. Because the limited study number, short trial duration, and inconsistent of GV index may contribute non-statistical. As my knowledge, TG can be possibly maintained to prevent insulin resistance. Hypertrophy of adipocytes on overloading TG significantly increases inflammatory status, especially tumour necrosis factor- $\alpha$ (TNF- $\alpha$ ) [30]. The reason is possibly that TG is the main maker to affect insulin resistance in the lipid metabolism. So the key question is what are the mechanisms on the reduced TG in type 2 diabetes? Inflammatory factor, especially TNF- $\alpha$, may be effected by GV, because of limitation of studies, we failed to explore the association between them. More theoretical work is needed to better understand the mechanism of GV, how it may be related to outcomes of interest and how to effectively change TG and inflammatory factor.

This meta-analysis has some limitations that should be considered. First, some of the studies had small sample size, especially meta-analysis of IMT levels. So caution is needed in the interpretation of the result from the meta-analysis, since the meta-analysis may have been underpowered. Second, in this metaanalysis, some studies were heterogeneous in terms of demographic characteristics and clinical features. This heterogeneity, as well as confounding factors such as different treatment, different measuring methods and limited clinical information, could affect the results. Nevertheless, the meta-analysis also has advantage. A strength of this study is to include studies published in English and Chinese languages, and no publication restrictions, all available data were included, thereby increasing the power of the study.

\section{Conclusion}

The healthy people maintain a balance in glucose uptake and production, and the GV could break the balance. And this meta-analysis show that minimizing GV is effective in improving the insulin resistance and IMT that are associated directly with cardiovascular disease. In other words, this analysis indicates that HOMA-IR and IMT possibly play an important role in glucose variability pathogenesis. Further studies are needed to determine how GV directly contribute to the pathogenesis of CVD in detail.

\section{Additional file}

Additional file 1: Figure S1. Effect of GV on BMI in type 2 diabetes. Figure S2. Effect of GV on WC in type 2 diabetes. Figure S3. Effect of GV on HDL in type 2 diabetes. Figure S4. Effect of GV on LDL in type 2 diabetes. Figure S5. Effect of GV on TC in type 2 diabetes. Figure S6. Effect of GV on Hs-CRP in type 2 diabetes. Figure S7. Effect of GV on HOMA-ßin type 2 diabetes (DOCX 2673 kb)

\section{Abbreviations \\ AMPK: AMP-activated protein kinase; BMI: Body Mass Index; \\ CVD: Cardiovascular disease; GV: Glucose variability; HbA1c: Glycosylated hemoglobin; HDL-C: HDL cholesterol; HGVG: High glucose variability group; HOMA: Homeostasis model assessment; Hs-CRP: High-sensitivity C-reactive protein; IMT: Carotid intima-media thickness; LDL-C: LDL cholesterol; LGVG: Low glucose variability group; MD: Mean difference; \\ PI3K: Phosphoinositide 3-kinase; SMD: Standardized mean difference; TC: Total cholesterol; TG: Triglyceride; TNF-a: Tumour-necrosis factor-a; WC: Waist circumference}

\section{Acknowledgements}

We would like to thank Yi Yuan, Hong Zhang and Yixuan Zhang at the Pharmaceutical University for the assisting in the recruitment of research on developing the search strategy and conducting the electronic search.

\section{Funding}

The meta-analysis was supported by National Natural Science Foundation of China (no. 81273588; 8,147,327).

\section{Availability of data and materials}

All original data comes from included studies, and manuscript submission includes many supplementary data of this meta-analysis.

\section{Authors' contributions}

SL contributed to the design of the review, extracted data, wrote the analysis plan, conducted the analysis, drafted and revised manuscript. XQL and $\mathrm{HH}$ revised the manuscript, LJX, HY and CXW contributed to the design of the review. All authors read and approved the final manuscript.

Ethics approval and consent to participate Not applicable.

Consent for publication Not applicable.

\section{Competing interests}

The authors declare that they have no competing interests.

\section{Publisher's Note}

Springer Nature remains neutral with regard to jurisdictional claims in published maps and institutional affiliations. 
Received: 7 July 2017 Accepted: 24 September 2017 Published online: 14 November 2017

\section{References}

1. Buse JB, Ginsberg HN, Bakris GL, Clark NG, Costa F, Eckel R, Fonseca V, Gerstein HC, Grundy S, Nesto RW, et al. Primary prevention of cardiovascular diseases in people with diabetes mellitus - a scientific statement from the American Heart Association and the American Diabetes Association. Circulation. 2007;115(1): 114-26.

2. Moss SE, Klein R, Klein BE. Cause-specific mortality in a population-based study of diabetes. Am J Public Health. 1991:81(9):1158-62

3. Arca M, Pigna G, Favoccia C. Mechanisms of diabetic dyslipidemia: relevance for atherogenesis. Curr Vasc Pharmacol. 2012;10(6):684-6.

4. Hall JE, Jones DW, Kuo JJ, da Silva A, Tallam LS, Liu J. Impact of the obesity epidemic on hypertension and renal disease. Curr Hypertens Rep. 2003;5(5): 386-92.

5. Cushman M, Arnold AM, Psaty BM, Manolio TA, Kuller LH, Burke GL, Polak JF, Tracy RP. C-reactive protein and the 10-year incidence of coronary heart disease in older men and women: the cardiovascular health study. Circulation. 2005:112(1):25-31.

6. Riddle MC. Effects of intensive glucose lowering in the management of patients with type 2 diabetes mellitus in the action to control cardiovascular risk in diabetes (ACCORD) trial. Circulation. 2010;122(8):844-6.

7. Stratton IM, Adler Al, Neil HA, Matthews DR, Manley SE, Cull CA, Hadden D, Turner RC, Holman RR. Association of glycaemia with macrovascular and microvascular complications of type 2 diabetes (UKPDS 35): prospective observational study. BMJ (Clinical research ed). 2000;321(7258):405-12.

8. Gerstein HC, Miller ME, Byington RP, Goff DC Jr, Bigger JT, Buse JB, Cushman WC, Genuth S, Ismail-Beigi F, Grimm RH Jr, et al. Effects of intensive glucose lowering in type 2 diabetes. N Engl J Med. 2008;358(24):2545-59.

9. Patel A, MacMahon S, Chalmers J, Neal B, Billot L, Woodward M, Marre M, Cooper M, Glasziou P, Grobbee D, et al. Intensive blood glucose control and vascular outcomes in patients with type 2 diabetes. N Engl J Med. 2008; 358(24):2560-72.

10. Duckworth W, Abraira C, Moritz T, Reda D, Emanuele N, Reaven PD, Zieve FJ, Marks J, Davis SN, Hayward R, et al. Glucose control and vascular complications in veterans with type 2 diabetes. N Engl J Med. 2009;360(2): 129-39.

11. Dadlani V, Kudva YC. Assessment of Interday glucose variability in type 2 diabetes. Diabetes Technol Ther. 2017:19(8):443-5.

12. Saisho Y. Glycemic variability and oxidative stress: a link between diabetes and cardiovascular disease? Int J Mol Sci. 2014;15(10):18381-406.

13. Su G, Mi S, Tao H, Li Z, Yang H, Zheng H, Zhou Y, Ma C. Association of glycemic variability and the presence and severity of coronary artery disease in patients with type 2 diabetes. Cardiovasc Diabetol. 2011;10:19.

14. Siegelaar SE, Kerr L, Jacober SJ, Devries JH. A decrease in glucose variability does not reduce cardiovascular event rates in type 2 diabetic patients after acute myocardial infarction: a reanalysis of the HEART2D study. Diabetes Care. 2011:34(4):855-7.

15. Liberati A, Altman DG, Tetzlaff J, Mulrow C, Gotzsche PC, loannidis JP, Clarke M, Devereaux PJ, Kleijnen J, Moher D. The PRISMA statement for reporting systematic reviews and meta-analyses of studies that evaluate health care interventions: explanation and elaboration. J Clin Epidemiol. 2009;62(10):e1-34

16. Jung HS. Clinical implications of glucose variability: chronic complications of diabetes. Endocrinology and metabolism (Seoul, Korea). 2015;30(2):167-74.

17. Higgins JP, Thompson SG, Deeks JJ, Altman DG. Measuring inconsistency in meta-analyses. BMJ (Clinical research ed). 2003;327(7414):557-60.

18. Egger M, Smith GD, Schneider M, Minder C. Bias in meta-analysis detected by a simple, graphical test. Br Med J. 1997;315(7109):629-34.

19. Bao YQ, Zhou J, Zhou M, Cheng YJ, Lu W, Pan XP, Tang JL, Lu HJ, Jia WP. Glipizide controlled-release tablets, with or without acarbose, improve glycaemic variability in newly diagnosed type 2 diabetes. Clin Exp Pharmacol Physiol. 2010;37(5-6):564-8.

20. Zhou SJ. The impact of glucose fluctuation on coronary arery disease severity in type 2 DM[Master], Shanxi Medical University; 2012.

21. Nalysnyk L, Hernandez-Medina M, Krishnarajah G. Glycaemic variability and complications in patients with diabetes mellitus: evidence from a systematic review of the literature. Diabetes Obes Metab. 2010;12(4):288-98.
22. Brohall G, Oden A, Fagerberg B. Carotid artery intima-media thickness in patients with type 2 diabetes mellitus and impaired glucose tolerance: a systematic review. Diabetic medicine : a journal of the British Diabetic Association. 2006;23(6):609-16.

23. Tehrani DM, Wong ND. Integrating biomarkers and imaging for cardiovascular disease risk assessment in diabetes. Current cardiology reports. 2016;18(11):105.

24. Lorenz MW, Markus HS, Bots ML, Rosvall M, Sitzer M. Prediction of clinical cardiovascular events with carotid intima-media thickness: a systematic review and meta-analysis. Circulation. 2007;115(4):459-67.

25. Wang C, Jin R, Nanda A, Yan J, Li G. Platelet Pl3Kgamma contributes to carotid Intima-media thickening under severely reduced flow conditions. PLoS One. 2015;10(6):e0129265.

26. Zineldeen DH, Keshk WA, Ghazy AH, El-Barbary AM. Sucrose non-fermenting AMPK related kinase/Pentraxin 3 and DNA damage axis: a gateway to cardiovascular disease in systemic lupus erythematosus among Egyptian patients. Ann Clin Biochem. 2016:53(2):240-51.

27. Bonora E, Formentini G, Calcaterra F, Lombardi S, Marini F, Zenari L, Saggiani F, Poli M, Perbellini S, Raffaelli A, et al. HOMA-estimated insulin resistance is an independent predictor of cardiovascular disease in type 2 diabetic subjects - prospective data from the Verona diabetes complicated study. Diabetes Care. 2002;25(7):1135-41.

28. Rask-Madsen C, Buonomo E, Li Q, Park K, Clermont AC, Yerokun O, Rekhter M, King GL. Hyperinsulinemia does not change atherosclerosis development in apolipoprotein E null mice. Arterioscler Thromb Vasc Biol. 2012;32(5):1124-31.

29. Bringhenti I, Ornellas F, Mandarim-de-Lacerda CA, Aguila MB. The insulinsignaling pathway of the pancreatic islet is impaired in adult mice offspring of mothers fed a high-fat diet. Nutrition (Burbank, Los Angeles County, Calif). 2016:32(10):1138-43.

30. Guilherme A, Virbasius JV, Puri V, Czech MP. Adipocyte dysfunctions linking obesity to insulin resistance and type 2 diabetes. Nat Rev Mol Cell Biol. 2008;9(5):367-77.

31. Mu P, Lu H, Zhang G, Chen Y, Fu J, Wang M, Shu J, Zeng L. Comparison of fasting capillary glucose variability between insulin glargine and $\mathrm{NPH}$. Diabetes Res Clin Pract. 2011:91:e4-7.

32. Yoo HJ, An HG, Park SY, Ryu OH, Kim HY, Seo JA, Hong EG, Shin DH, Kim $\mathrm{YH}$, Kim SG, et al. Use of a real time continuous glucose monitoring system as a motivational device for poorly controlled type 2 diabetes. Diabetes Res Clin Pract. 2008;82(1):73-9.

33. Su G, Su J, Wang $L$, et al. Effect of aerobic exercise training on glycemic variability and islet $\beta c e l l$ function in type 2 diabetes mellitus in early stage. Jiangsu Med J. 2014(02):180-2.

34. Lin SD, Wang JS, Hsu SR, Sheu WH, Tu ST, Lee IT, Su SL, Lin SY, Wang SY, Hsieh MC. The beneficial effect of alpha-glucosidase inhibitor on glucose variability compared with sulfonylurea in Taiwanese type 2 diabetic patients inadequately controlled with metformin: preliminary data. J Diabetes Complicat. 2011;25(5):332-8.

35. Yuan G, Hu H, Wang S, Yang Q, Yu S, Sun W, Qian W, Mao C, Zhou L, Chen D, et al. Improvement of beta-cell function ameliorated glycemic variability in patients with newly diagnosed type 2 diabetes after short-term continuous subcutaneous insulin infusion or in combination with sitagliptin treatment: a randomized control trial. Endocr J. 2015;62(9):817-34.

36. Sun W, Zeng C, Liao L, Chen J, Wang Y. Comparison of acarbose and metformin therapy in newly diagnosed type 2 diabetic patients with overweight and/or obesity. Curr. Med. Res. Opin. 2016;32(8):1389-96.

37. Kim HS, Shin JA, Lee SH, Kim ES, Cho JH, Son HY, Yoon KH. A comparative study of the effects of a dipeptidyl peptidase-IV inhibitor and sulfonylurea on glucose variability in patients with type 2 diabetes with inadequate glycemic control on metformin. Diabetes Technol Ther. 2013:15(10):810-6.

38. Natale C, Annuzzi G, Bozzetto L, Mazzarella R, Costabile G, Ciano O, Riccardi G, Rivellese AA. Effects of a plant-based high-carbohydrate/high-fiber diet versus high-monounsaturated fat/low-carbohydrate diet on postprandial lipids in type 2 diabetic patients. Diabetes Care. 2009:32:2168-73.

39. Cho JH, Chang SA, Kwon HS, Choi YH, Ko SH, Moon SD, Yoo SJ, Song KH, Son HS, Kim HS, et al. Long-term effect of the internet-based glucose monitoring system on $\mathrm{HbA} 1 \mathrm{c}$ reduction and glucose stability: a 30-month follow-up study for diabetes management with a ubiquitous medical care system. Diabetes Care. 2006;29(12):2625-31.

40. Bibra H, Siegmund T, Kingreen I, Riemer M, Schuster T, Schumm-Draeger PM. Effects of analogue insulin in multiple daily injection therapy of type 2 
diabetes on postprandial glucose control and cardiac function compared to human insulin: a randomized controlled long-term study. Cardiovasc Diabetol. 2016;15

41. Buse JB, Rodbard HW, Trescoli Serrano C, Luo J, Ivanyi T, Bue-Valleskey J, Hartman ML, Carey MA, Chang AM. Randomized clinical trial comparing basal insulin Peglispro and insulin Glargine in patients with type 2 diabetes previously treated with basal insulin: IMAGINE 5. Diabetes Care. 2016;39(1):92-100.

42. Mita T, Katakami N, Yoshii H, Onuma T, Kaneto H, Osonoi T, Shiraiwa T, Kosugi K, Umayahara Y, Yamamoto T, et al. Alogliptin, a Dipeptidyl peptidase 4 inhibitor, prevents the progression of carotid atherosclerosis in patients with type 2 diabetes: the study of preventive effects of Alogliptin on diabetic atherosclerosis (SPEAD-A). Diabetes Care. 2016;39(1): 139-48.

43. Tay J, Luscombe-Marsh ND, Thompson CH, Noakes M, Buckley JD, Wittert GA, Yancy WS Jr, Brinkworth GD. A very low-carbohydrate, low-saturated fat diet for type 2 diabetes management: a randomized trial. Diabetes Care. 2014;37(11):2909-18.

44. Tay J, Luscombe-Marsh ND, Thompson CH, Noakes M, Buckley JD, Wittert GA, Yancy WS Jr, Brinkworth GD. Comparison of low- and highcarbohydrate diets for type 2 diabetes management: a randomized trial. Am J Clin Nutr. 2015;102(4):780-90.

45. Wan H, Zhao D, Shen J, Lu L, Zhang T, Chen Z. Comparison of the effects of continuous subcutaneous insulin infusion and add-on therapy with sitagliptin in patients with newly diagnosed type 2 diabetes mellitus. In: Journal of Diabetes Research vol. 2016;2016

46. Huang Z. The effect and comparison of Atorvastatin and itavastatin on blood lipids and blood glucose in elderly type 2 diabetic patients[master]: Central South University; 2012.

47. Zhou Q. Clinic study on insulin pump curing type 2 diabetes mellitus[master]. China: Jilin University; 2008.

48. Ye YZ. Research on the relationship between glucose fluctuations and oxidative stress in newly diagnosed type 2 diabetes mellitus[master]: Dalian Medical University; 2014.

49. HE RT, LU Xiao F, WU JX, et al. A retrospective study on the risk of long-term albuminuria in newly diagnosed type 2 diabetic patients after continuous subcutaneous insulin infusion therapy. Chin J Diabetes. 2016;03:210-3.

50. Wang RP, Lou J, Hu YW, Liu JP, Zhang QY. Effect of different medical nutrition therapy on blood glucose fluctuation in elderly type 2 diabetes mellitus patients. Chongqing Medicine. 2015;28:3921-4.

\section{Submit your next manuscript to BioMed Central and we will help you at every step:}

- We accept pre-submission inquiries

- Our selector tool helps you to find the most relevant journal

- We provide round the clock customer support

- Convenient online submission

- Thorough peer review

- Inclusion in PubMed and all major indexing services

- Maximum visibility for your research

Submit your manuscript at www.biomedcentral.com/submit

) Biomed Central 